\title{
DISTAMGE COVERED BELOW AND ABOVE THE ANAEROBIC THRESHOLD BY ELITE GERMAN GOALKEEPERS
}

\author{
Przemysław Parus, 1, A, B, C, D Paweł Chmura, 2, A, B, C, D Marek Konefał, ${ }^{1, A, B C, D}$ \\ Marcin Andrzejewski, ${ }^{3, A, C, D}$ Edward Kowalczuk, ${ }^{4, B, D}$ Jan Chmura, ${ }^{1,}, \mathrm{D}, \mathrm{E}$
}

\author{
${ }^{1}$ Department of Biological and Motor Sport Bases, University School of Physical Education, Wrocław, Poland \\ ${ }^{2}$ Department of Team Games, University School of Physical Education, Wrocław, Poland \\ ${ }^{3}$ Department of Recreation, University School of Physical Education, Poznań, Poland \\ ${ }^{4}$ Football Club, Hannover 96, Robert-Enke-Str. 1, Germany \\ A Study Design; ${ }^{\mathrm{B}}$ Data Collection; ${ }^{\mathrm{C}}$ Statistical Analysis; ${ }^{\mathrm{D}}$ Manuscript Preparation; ${ }^{\mathrm{E}}$ Founds Collection
}

\author{
Address for corpespondence: \\ Przemysław Parus, \\ University School of Physical Education, Departament of Biological and Motor Sport Bases, \\ I.J. Paderewskiego 35, 51-612 Wrocław, Poland \\ Email: par91@poczta.onet.pl
}

\begin{abstract}
Ahstract The study aimed to assess the total covered distance during a match, performance volume below and above the anaerobic threshold, as well as characterize physical activities of professional Bundesliga goalkeepers during soccer matches. 34 goalkeepers (606 observations) from all eighteen Bundesliga teams, who played in the 2014/2015 season were considered for the study. The performance of goalkeepers was analyzed with the use of the VIS.TRACK system. The variables measured included: total covered distance $[\mathrm{km}]$ in the whole match, the first half, and the second half; distance covered below and above the anaerobic threshold $\left(4 \mathrm{~m} \cdot \mathrm{s}^{-1}\right)[\mathrm{km}]$; and distance covered in six intensity ranges [km]. The total distance covered by the goalkeepers was $5.48 \pm 0.56 \mathrm{~km}$. The distance covered by goalkeepers below the anaerobic threshold was $5.28 \pm 0.52 \mathrm{~km}$, whereas the distance covered above the anaerobic threshold amounted to $0.21 \pm 0.09 \mathrm{~km}$. The ratio between the goalkeepers' volumes of aerobic and anaerobic performance was 25:1. The total distance covered by goalkeepers in match play and the distances covered by goalkeepers below and above the anaerobic threshold ( $96.17 \%$ and $3.83 \%$, respectively) indicate that during a match the goalkeepers undertake predominantly aerobic exercises.
\end{abstract}

Key worlls soccer, goalkeeper, anaerobic threshold, Bundesliga, covered distance

\section{Introduction}

Modern association football demands high levels of physical preparation from goalkeepers (Hazir, 2010; Boone, Vaeyens, Steyaert, Vanden Bossche, Bourgois, 2012; Chmura et al., 2015). More and more often, goalkeepers tend to cooperate with different players in all other positions and engage in offensive actions outside the penalty area (Szwarc, Lipińska, Chamera, 2010). This is related to the goalkeepers' necessity to perform a greater number of activities of variable intensity such as sprinting, low-, moderate- and high-speed running, jogging, walking and standing (Di Salvo, Benito, Calderón, Di Salvo, Pigozzi, 2008). It also affects the changes 
in the distance covered by goalkeepers during a match. According to Chmura et al. (2015) covered distance is one of practical measures of players' endurance capacity. Boone, Vaeyens, Steyaert, Vanden Bossche, Bourgois (2012) showed that a goalkeeper covers a distance of $4 \mathrm{~km}$ during a single soccer match. Other authors showed that goalkeepers can run up to 5.65 km in a match (Di Salvo, Benito, Calderón, Di Salvo, Pigozzi, 2008; Ademović, Čolakhodžić, Talović, Kajmović, 2012; Chmura et al., 2012), and even, in some cases, up to 6.99 km (Bojkowski, Śliwowski, Wieczorek, Eider, 2015).

A goalkeeper's physical activity, like outfielders' activity, requires a proper level of aerobic capacity (Bravo et al., 2007; Hazir, 2010; Wiacek, Andrzejewski, Chmura, Zubrzycki, 2011; Alghannam, 2012; Boone, Vaeyens, Steyaert, Vanden Bossche, Bourgois, 2012). It should be noted that $73 \%$ of distance covered by goalkeepers is walking $\left(0.3-7.2 \mathrm{~km} \cdot \mathrm{h}^{-1}\right)$ (Di Salvo, Benito, Calderón, Di Salvo, Pigozzi, 2008). According to Di Salvo, Benito, Calderón, Di Salvo, Pigozzi (2008) and Ademović, Čolakhodžić, Talović, Kajmović (2012) goalkeepers also perform from $2.00 \pm 2.00$ to $8.10 \pm 5.58$ sprints in a game, as well as numerous other short-lasting and explosive motor activities such as jumps, digs, and ball catches (Hazir, 2010). Fast game play during which players perform many high-intensity actions involves a great deal of anaerobic energy metabolism (Bravo et al., 2007; Hazir, 2010; Wiacek, Andrzejewski, Chmura, Zubrzycki, 2011; Alghannam, 2012; Boone, Vaeyens, Steyaert, Vanden Bossche, Bourgois, 2012). Thus, like in outfielders, the goalkeepers' level of anaerobic capacity is also highly significant.

Determining exercise intensity at the anaerobic threshold (AT) is crucial in training practice (Chmura et al., 2015). There are different methods of determining AT, which occurs at $4 \mathrm{mmol} \cdot \mathrm{I}^{-1}$ of lactate concentration (Keul, Dickhuth, Berg, Lehmann, Huber, 1981; Magiera, Janczak, Niemierzycka, Cabak, Zbrodowska, 2006). The anaerobic threshold also appears frequently during running at $4 \mathrm{~m} \cdot \mathrm{s}^{-1}$ (Śliwowski et al., 2013; Chmura et al., 2015; Andrzejewski, Konefał, Chmura, Kowalczuk, Chmura, 2016). Crossing the AT leads to rapid accumulation of metabolic acidosis and blood lactate (Śliwowski et al., 2013; Chmura et al., 2015; Andrzejewski, Konefał, Chmura, Kowalczuk, Chmura, 2016).

During a soccer match players perform efforts above and below the anaerobic threshold. Each short-term maximal intensity exercise is regarded as an above-the-threshold effort. The performance of such exercise by soccer players may lead to an increase in lactate blood level to $14 \mathrm{mmol} \cdot \mathrm{l}^{-1}$ (Bishop, Girard, 2013). During match play a goalkeeper must maintain a high level of mobilization and concentration, quickly react to audiovisual stimuli, make optimal decisions, and display a high level of differentiation between important and unimportant stimuli. All of these capacities can be only reached, if a goalkeeper is able to cross the anaerobic threshold at an exercise intensity close to psychomotor fatigue threshold (PFT) (Chmura, Nazar, Kaciuba-Uściłko, 2007; Chmura, Wiśnik, 2008; Chmura, Nazar, 2010).

Research provides numerous data on the total distance covered by goalkeepers. There have not been, however, studies on the total distance covered by goalkeepers in the first half and the second half of the match, and on the distance covered below and above the anaerobic threshold. There have been also few studies on the range of intensity of activities performed by goalkeepers. Such data are of key significance for the optimization of goalkeeping training. The aim of the present study was to determine the total distance covered below and above the anaerobic threshold, and to analyze physical activities by professional German goalkeepers during actual competitive matches. 


\section{Material and methods}

The study group consisted of 34 goalkeepers (606 observations, 34 rounds) representing all eighteen German Bundesliga teams in the $2014 / 2015$ season. Only goalkeepers who played the whole matches were examined. They were $26.79 \pm 4.05$ years of age, $189.64 \pm 3.32 \mathrm{~cm}$ of body height, $84.73 \pm 4.96 \mathrm{~kg}$ of body mass, and BMI of 23.55 $\pm 1.03 \mathrm{~kg} / \mathrm{m}^{2}$. The study did not require the players' informed consent as it was carried out by an external company (IMPIRE AG).

Goalkeepers' activity was assessed using the VIS.TRACK system (IMPIRE AG, Germany) using the recording frequency of $25 \mathrm{~Hz}$. Each goalkeeper's movement was recorded by two cameras (Link, Weber, 2015). The VIS. TRACK system uses the state-of-the-art algorithms and 2D and 3D video recording technology, allowing a detailed motion analysis of entire soccer matches (www.impire.de). The system can analyze the covered distance, running speed and actions in match play, also acknowledging players' performance below and above the anaerobic threshold amounting to $4 \mathrm{~m} \cdot \mathrm{s}^{-1}$ (Śliwowski et al., 2013; Chmura et al., 2015). The reliability and accuracy of the VIS.TRACK system have been attested by various authors (Tiedemann, Francksen, Latacz-Lohmann, 2010; Stulp, Kordsmeyer, Buunk, Verhulst, 2012; Chmura et al., 2015; Link, Weber, 2015).

The following variables were subject to analysis: total covered distance $[\mathrm{km}]$ during the whole match, in the first half, and in the second half; distance covered [km] below and above the anaerobic threshold [km] in six intensity ranges: $0-11 \mathrm{~km} \cdot \mathrm{h}^{-1}, 11-14 \mathrm{~km} \cdot \mathrm{h}^{-1}, 14-17 \mathrm{~km} \cdot \mathrm{h}^{-1}, 17-21 \mathrm{~km} \cdot \mathrm{h}^{-1}, 21-24 \mathrm{~km} \cdot \mathrm{h}^{-1}$, and $\geq 24 \mathrm{~km} \cdot \mathrm{h}^{-1}$; percent of the covered distance below and above the AT in the entire match; and ratio between aerobic and anaerobic performance volume. Additionally, the percent of covered distance in individual intensity ranges was also calculated.

For all examined variables their conformity with normal distribution was checked with the KolmogorovSmirnov test $(p>0.2)$. Arithmetic means, standard deviations and minimum and maximum values were calculated. Student's t-test was used to compare the covered distances in the first and the second halves. The level of statistical significance was set at $p \leq 0.05$. All statistical calculations were made with STATISTICA 12.0.

\section{Results}

The analysis revealed that the total distance covered by the goalkeepers was $5.48 \pm 0.56 \mathrm{~km}$ ( $\mathrm{min}-3.77 \mathrm{~km}$, max $-6.92 \mathrm{~km})$. The mean covered distance in the first half was $2.74 \pm 0.29 \mathrm{~km}$, and in the second $2.75 \pm 0.32 \mathrm{~km}$. No statistically significant differences were found between the covered distances in the first and the second halves of the match (Figure 1). 


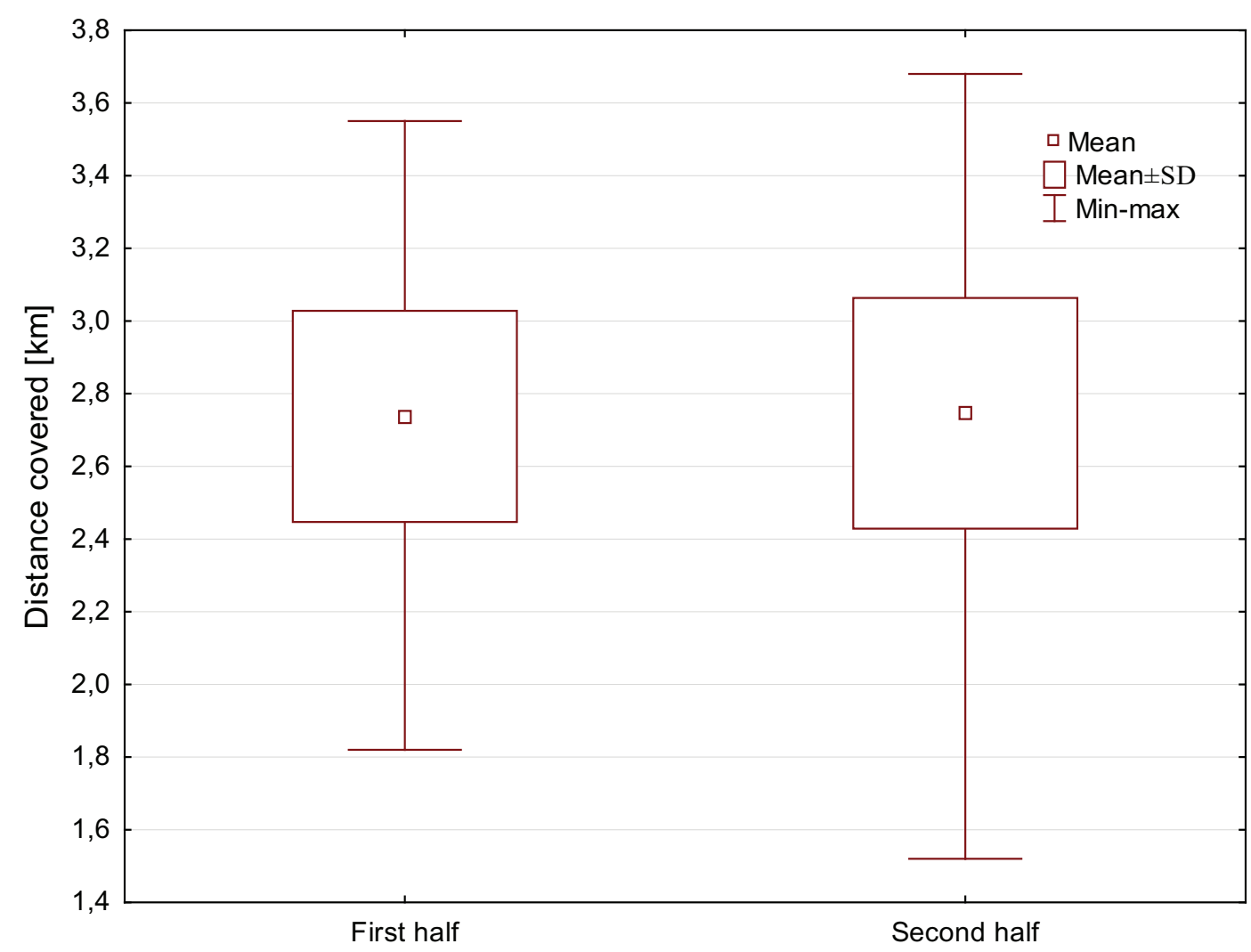

Figure 1. Differences in distance covered by goalkeepers in the first and the second halves of the match

The distance covered by goalkeepers below the anaerobic threshold amounted to $5.28 \pm 0.52 \mathrm{~km}$, i.e. $96.17 \%$ of total covered distance ( $\min -3.57 \mathrm{~km}$, max $-6.64 \mathrm{~km}$ ). The distance covered by goalkeepers above the AT was $0.21 \pm 0.09 \mathrm{~km}$, i.e. $3.83 \%$ of total covered distance (from $0.03 \mathrm{~km}$ to $0.58 \mathrm{~km}$ ). The ratio between aerobic and anaerobic performance volume was 25:1.

The studied goalkeepers covered the distance of $4.92 \pm 0.47 \mathrm{~km}$ at $0-11 \mathrm{~km} \cdot \mathrm{h}^{-1}(89.86 \pm 3.01 \%$ of total covered distance); $0.33 \pm 0.11 \mathrm{~km}(5.95 \pm 1.71 \%)$ at $11-14 \mathrm{~km} \cdot \mathrm{h}^{-1} ; 0.14 \pm 0.06 \mathrm{~km}(2.59 \pm 0.89 \%)$ at $14-17 \mathrm{~km} \cdot \mathrm{h}^{-1}$; $0.07 \pm 0.04 \mathrm{~km}(1.22 \pm 0.58 \%)$ at $17-21 \mathrm{~km} \cdot \mathrm{h}^{-1} ; 0.02 \pm 0.01 \mathrm{~km}(0.29 \pm 0.25 \%)$ at $21-24 \mathrm{~km} \cdot \mathrm{h}^{-1} ;$ and $0.01 \pm 0.01 \mathrm{~km}$ at $\geq 24 \mathrm{~km} \cdot \mathrm{h}^{-1}(0.10 \pm 0.18 \%)$ (Table 1$)$. 
Table 1. Mean distances covered by goalkeepers during a Bundesliga match

\begin{tabular}{cccc|ccc}
\hline Intensity range & \multicolumn{3}{c|}{ Distance covered $[\mathrm{km}]$} & \multicolumn{3}{c}{ Distance covered [\%] } \\
\cline { 2 - 7 }$\left[\mathrm{km} \cdot \mathrm{h}^{-1}\right]$ & $\overline{\mathrm{x}} \pm \mathrm{SD}$ & Min. & Max. & $\overline{\mathrm{x}} \pm \mathrm{SD}$ & Min. & Max. \\
\hline$<11$ & $4.92 \pm 0.47$ & 3.33 & 6.13 & $89.86 \pm 3.01$ & 79.00 & 96.50 \\
$11-14$ & $0.33 \pm 0.11$ & 0.10 & 0.73 & $5.95 \pm 1.71$ & 2.10 & 11.20 \\
$14-17$ & $0.14 \pm 0.06$ & 0.03 & 0.36 & $2.59 \pm 0.89$ & 0.60 & 5.50 \\
$17-21$ & $0.07 \pm 0.04$ & 0.00 & 0.24 & $1.22 \pm 0.58$ & 0.10 & 3.80 \\
$21-24$ & $0.02 \pm 0.01$ & 0.00 & 0.10 & $0.29 \pm 0.25$ & 0.00 & 1.70 \\
$>24$ & $0.01 \pm 0.01$ & 0.00 & 0.09 & $0.10 \pm 0.18$ & 0.00 & 1.40 \\
\hline
\end{tabular}

\section{Discussion}

In recent years increased game speed and distance covered by goalkeepers have been observed in soccer competitions (Ademović, Čolakhodžić, Talović, Kajmović, 2012). The results of the present study show that goalkeepers playing in the German Budesliga in the 2014/2015 season covered the distance of $5.48 \pm 0.56 \mathrm{~km}$, with the longest recorded distance of $6.92 \mathrm{~km}$. These results correspond to the findings of Di Salvo, Benito, Calderón, Di Salvo, Pigozzi (2008) in the English Premier League (5.61 $\pm 0.61 \mathrm{~km}$ ). Bojkowski etal. (2015) noted that goalkeepers taking part in the 2014 World Cup covered the mean distance of $5.65 \mathrm{~km}$, with the longest distance of $6.99 \mathrm{~km}$. This indicates that goalkeepers covered a two-time shorter distance that the outfielders (Andrzejewski, Chmura, Pluta, Kasprzak, 2012; Di Salvo, Baron, Tschan, Calderon Montero, Bachl, Pigozzi, 2007; lonică, 2013; Soroka, 2013). The present study did not reveal statistically significant differences between the distances covered by a goalkeeper in the first and the second half of the match. Similar observations were made by Di Salvo, Benito, Calderón, Di Salvo, Pigozzi (2008), which indicates that goalkeepers' performance in both match halves is at similar level. Alghannam (2012) found that the distance covered by outfielders in the second half of a match decreases due to their increased fatigue. Considering the distance covered in both halves of the match, differences in performed physical activities can be noted between goalkeepers and outfielders (Di Salvo, Baron, Tschan, Calderon Montero, Bachl, Pigozzi, 2007; Di Salvo, Benito, Calderón, Di Salvo, Pigozzi, 2008; Andrzejewski, Chmura, Pluta, Kasprzak, 2012).

During a match a goalkeeper performs both aerobic and anaerobic activities. The former is confirmed by the distance covered below the anaerobic threshold, which amounted to $5.28 \pm 0.52 \mathrm{~km}$ in the present study, i.e. $96.17 \%$ of the total covered distance. A goalkeeper, therefore, mostly performs exercises below the anaerobic threshold. The analysis of goalkeepers' activities above the anaerobic threshold showed that the studied Bundesliga goalkeepers covered $0.21 \pm 0.09 \mathrm{~km}$ during a match, i.e. $3.83 \%$ of total covered distance. The level of anaerobic exercise performed by goalkeepers is eight-times lower than that of outfielders. This is confirmed by lonică (2013), who revealed that anaerobic performance by all players amounted to $30 \%$ of all match activity. The present study only focused on covered distance; however, it did not consider such goalkeepers' activities as jumps, digs and ball catches, which are definitely anaerobic exercises characteristic for goalkeepers. Since goalkeepers perform a great number of such exercises during a game, which also generate anaerobic power, the percent of anaerobic exercises by all team players can be even lower. Due to the frequent performance of short-duration activities by goalkeepers, their training must account for development of power and explosive strength (Chmura, Chmura, Ciastoń, 2008). Data on distance covered below and above the anaerobic threshold during a match reveal the aerobic to anaerobic 
exercise ratio of 25:1. This underlines the significance of aerobic processes for goalkeepers' motor preparation. The proper aerobic to anaerobic exercise ratio can also improve the effectiveness of power and explosive strength training (Chmura, Chmura, Ciastoń, 2008).

The goalkeeper's performance is also characterized by the distance covered in match play at various running intensities. The analysis showed that the distances of $4.92 \pm 0.47 \mathrm{~km}$ covered by goalkeepers below $11 \mathrm{~km} \cdot \mathrm{h}^{-1}$, $(89.86 \pm 3.01 \%)$ and $0.33 \pm 0.11 \mathrm{~km}$ at $11-14 \mathrm{~km} \cdot \mathrm{h}^{1}(5.95 \pm 1.71 \%)$ constitute together $95.63 \%$ of the total covered distance. Similar results were obtained by Ademović, Čolakhodžić, Talović, Kajmović (2012). Moreover, Soroka (2013) noted that depending on game tactics, goalkeepers cover from $3.53 \mathrm{~km}$ to $3.72 \mathrm{~km}$ at $\leq 11 \mathrm{~km} \cdot \mathrm{h}^{-1}$, and from $0.23 \mathrm{~km}$ to $0.25 \mathrm{~km}$ at $11 \leq 14 \mathrm{~km} \cdot \mathrm{h}^{-1}$, i.e. $90 \%$ of total covered distance during the entire match. In the present study the Bundesliga goalkeepers covered $4.37 \%$ of the total distance in the intensity range from $14 \mathrm{~km} \cdot \mathrm{h}^{-1}$ to above $24 \mathrm{~km} \cdot \mathrm{h}^{-1}$, similarly to Di Salvo, Benito, Calderón, Di Salvo, Pigozzi (2008). Despite the uses of different systems of motion analysis in different studies, the results concerning covered distances in different intensity ranges are similar (Di Salvo, Benito, Calderón, Di Salvo, Pigozzi, 2008; Ademović, Čolakhodžić, Talović, Kajmović, 2012; Soroka, 2013). The obtained data on distances covered by goalkeepers in six intensity ranges show that the higher intensity of exercise goalkeepers tend to cover shorter distances.

\section{Practical application}

Appropriate anaerobic training of soccer players based on aerobic foundations can be a significant determinant of match outcome. A goalkeeper who performs activities at a high maximal oxygen uptake, crosses the anaerobic threshold, maintains exercise intensity between the anaerobic threshold and the threshold of psychomotor fatigue, is able to quickly respond to rapidly changing situations in match play, including shots at goal. Activities performed by soccer players, including goalkeepers, between the two thresholds increase reaction speed, accuracy and concentration (Chmura, Wiśnik, 2008; Chmura, Nazar, 2010). However, in match conditions goalkeepers are not often forced to undertake exercises of such intensities. Thus coaches should draw goalkeepers' attention to the necessity of performing stimulating exercises allowing crossing the anaerobic threshold. Goalkeepers' precompetitive preparation should accommodate endurance-speed training to enhance the tolerance of incremental fatigue.

\section{Conclusions}

1. The total distance covered by goalkeepers in a match and the distances covered by goalkeepers below and above the anaerobic threshold $(96.17 \%$ and $3.83 \%$, respectively) indicate that during a soccer match goalkeepers undertake predominantly aerobic exercises.

2. Similar distances covered by goalkeepers in the first and the second halves of the match are evidence of the similar levels of goalkeepers' activity in both halves of the match.

3. The ratio between activities performed below and above the anaerobic threshold, amounting to $25: 1$, is a significant factor for modern goalkeeping training. Goalkeepers' preparation must account for the appropriate volume of aerobic and anaerobic training. 


\section{References}

Ademović, A., Čolakhodžić, E., Talović, M., Kajmović, H. (2012). Top footballer model based on indicators of situational efficiency in the Round of 16 at the 2010 FIFA World Cup. Homo Sporticus, 14 (2), 33-40.

Alghannam, A.F. (2012). Metabolic limitations of performance and fatigue in football. Asian Journal of Sports Medicine, 3 (2), 65-73.

Andrzejewski, M., Chmura, J., Pluta, B., Kasprzak, A. (2012). Analysis of Motor Activities of Professional Soccer Players. Journal of Strength and Conditioning Research, 26 (6), 1481-1488.

Andrzejewski, M., Konefał, M., Chmura, P., Kowalczuk, E., Chmura, J. (2016). Match outcome and distances covered at various speeds in match play by elite German soccer players. International Journal of Performance Analysis in Sport, 16, 818-829.

Bishop, D. J., Girard, O. (2013). Determinants of team-sport performance: implications for altitude training by team-sport athletes British Journal of Sports Medicine, 47 (Suppl 1), i17-i21.

Bojkowski, Ł., Śliwowski, R., Wieczorek, A., Eider, J. (2015). Analysis of the longest distances run by the best soccer players at the FIFA World Cup in Brazil in 2014. Central European Journal of Sport Sciences and Medicine, 11 (3), 145-151.

Boone, J., Vaeyens, R., Steyaert, A., Vanden Bossche L., Bourgois, J. (2012). Physical fitness of elite Belgian soccer players by player position. Journal of Strength and Conditioning Research, 26 (8), 2051-2057.

Bravo, F.D., Impellizzeri, F.M., Rampinini, E., Castagna, C., Bishop, D.J., Wisloff, U. (2007). Sprint vs. interval training in football. International Journal of Sports Medicine, 29, 668-674.

Chmura, J., Nazar, K., Kaciuba-Uściłko, H. (2007). Próg psychomotoryczny zmęczenia. Sport Wyczynowy, 4-6 (508-510), 27-35.

Chmura, J., Wiśnik, P. (2008). Próg psychomotoryczny zmęczenia-implikacje praktyczne (na przykładzie gry w piłkę nożną). Sport Wyczynowy, 1-3 (517-519), 55-61.

Chmura, J., Chmura, P., Ciastoń, J. (2008). Przygotowanie motoryczne piłkarzy do wysiłku startowego. Sport Wyczynowy, 10-12 (526-528), 49-61.

Chmura, J., Nazar, K. (2010). Parallel changes in the onset of blood lactate accumulation (OBLA) and threshold of psychomotor performance deterioration during incremental exercise after training in athletes. International Journal of Psychophysiology, 75 (3), 287-290.

Chmura, J., Oh, S. D., Min, S. K., Chmura, P., Kawczyński, A., Mroczek, D., Szyngiera, W. (2012). Zdolności wytrzymałościowe piłkarzy - uczestników Mistrzostw Świata w Piłce Nożnej w 2010 roku. Sport Wyczynowy, 2, 48-57.

Chmura, P., Konefał, M., Kowalczuk, E., Andrzejewski, M., Rokita, A., Chmura, J. (2015). Distances Covered above and below the Anaerobic Threshold by Professional Football Players in Different Competitive Conditions. Central European Journal of Sport Sciences and Medicine, 10 (2), 25-31.

Di Salvo, V., Baron, R., Tschan, H., Calderon Montero, F.J., Bachl, N., Pigozzi, F. (2007). Performance characteristics according to playing position in elite soccer. International Journal of Sports Medicine, 28, 222-227.

Di Salvo, V., Benito, P.J., Calderón, F.J., Di Salvo, M., Pigozzi, F. (2008). Activity profile of elite goalkeepers during football match-play. Journal of Sports Medicine and Physical Fitness, 48 (4), 443-446.

Hazir, T. (2010). Physical Characteristics and Somatotype of Soccer Players according to Playing Level and Position. Journal of Human Kinetics, 26, 83-95.

Ionică, C. (2013). Aspects Regarding the Role and the Importance of Physical Preparation in the Modern Football Game. Timisoara Physical Education and Rehabilitation Journal, 5 (10), 61-65.

Keul, J., Dickhuth, H.H., Berg, A., Lehmann, M., Huber, G. (1981). Allgemeine und sportartspezifische Leistungsdiagnostik im Hochleistungsbereich. Leistungssport, 11 (5), 382-398.

Link, D., Weber, H. (2015). Effect of Ambient Temperature on Pacing in Soccer depends on Skill Level Running head: Temperature Soccer. Journal of Strength and Conditioning Research, 1-17.

Magiera, A., Janczak, Z., Niemierzycka, A., Cabak, A., Zdrodowska, A. (2006). Ocena progu przemian beztlenowych w warunkach laboratoryjnych - porównanie metod. Polish Journal of Sports Medicine, 22 (5), 262-266.

Soroka, A. (2013). Sprawność działania piłkarzy nożnych w systemach gry preferowanych podczas mistrzostw świata w 2010 roku. Roczniki Naukowe Wyższej Szkoły Wychowania Fizycznego i Turystyki w Białymstoku, 45-50.

Stulp, G., Kordsmeyer, T., Buunk, A. P., Verhulst, S. (2012). Increased aggression during human group contests when competitive ability is more similar. Biology Letters, 8, 921-923.

Szwarc, A., Lipińska, P., Chamera, M. (2010). The efficiency model of goalkeeper's actions in soccer. Baltic Journal of Health and Physical Activity, 2 (2), 132-138. 
Śliwowski, R., Andrzejewski, M., Wieczorek, A., Barinow-Wojewódzki, A., Jadczak, Ł., Adrian, J., Pietrzak, M., Wieczorek, J. (2013). Changes in the anaerobic threshold in an annual cycle of sport training of young soccer players. Biology of Sport, 30 (2), $137-143$.

Tiedemann, T., Francksen, T., Latacz-Lohmann, U. (2011). Assessing the performance of German Bundesliga football players: a nonparametric meta-frontier approach. Central European Journal of Operations Research, 19 (4), 571-587.

Wiacek, M., Andrzejewski, M., Chmura, J., Zubrzycki, I.Z. (2011). The changes of the specific physiological parameters in response to 12-week individualized training of young soccer players. Journal of Strength and Conditioning Research, 25 (6), $1514-1521$.

www.impire.de

Cite this anticle as: Parus, P., Chmura, P., Konefał, M., Andrzejewski, M., Kowalczuk, E., Chmura, J. (2017). Distance Covered Below and Above the Anaerobic Threshold by Elite German Goalkeepers. Central European Journal of Sport Sciences and Medicine, 17 (1), 25-32. DOI: 10.18276/cej.2017.1-03. 